\title{
Analysis of the endangered monuments in the Masovian Voivodeship, excluding Warsaw
}

\author{
Emilia Dudzińska \\ https://orcid.org/0000-0003-0201-8514 \\ emilia.dudzinska.dokt@pw.edu.pl \\ Faculty of Architecture, Warsaw University of Technology
}

\begin{abstract}
This paper is devoted to analysing the endangered heritage buildings under law protection in Masovian Voivodeship (Poland) that have not lost heritage values. The methodology based on source research. The study presents the division to the most numerous categories: the original function, time of creation, location, and others. The paper presents the results showing categories under increased threat and identifies the need to perform such analysis for other voivodeships that can help to channel the resources to prevent further destruction of most endangered categories. That includes performing detailed surveys to secure spatial information about buildings under discussion.
\end{abstract}

Keywords: Gródkowo, Kopana, endangered heritage, Masovian Voivodeship, heritage value

\section{Introduction}

Masovian Voivodeship is one of 16 Voivodeships and is located in central Poland. Its capital city is Warsaw, which is also the country's capital city. It is the biggest voivodeship, considering the area and population. It is divided into 37 counties. From the heritage management point of view, the Masovian Voivodeship the central unit (Mazowiecki Wojewódzki Konserwator Zabytków) has its headquater in Warsaw. There are also five delegations responsible for specified counties: Delegation in Ciechanów, Delegation in Ostrołęka, Delegation in Płock, Delegation in Radom, Delegation in Siedlce.

This paper discusses endangered heritage buildings. There is no objective methodology for the assessment of a building's condition, so the buildings under consideration rely on reports developed by the National Heritage Board of Poland [1] [2].

The research aimed to analyse the number, function, chronology and other factors that would enable to identify the groups at the highest risk.

\section{Masovian Voivodeship endangered heritage Characteristics}

As for 30.04.2016 in the Masovian Voivodeship, there were 7176 listed heritage immovable monuments that make $10.12 \%$ of the national number of 70885 entries [2]. This number is one of the highest in Poland (the number is higher only in Dolvośląskie nad Wielkoposkie Voivodeship.

The endangered items that did not lose historic values made $2.62 \%$ with the number of 168 entries (placing it as third from the end, considering the highest number of items at risk. Considering the function of elements under discussion, the group with the highest number, both in percentage and quantity, are residential structures. For the construction material, brick buildings have the highest representation. Considering the time of creation the most prominent group are entries created in the XIX century. The division, according to the type 
of ownership, the most numerous group are private buildings (53 buildings, $4.41 \%$ ). This analysis contains buildings and greenery, commentaries and elements classified as "other".

Compared to numbers in the national context, the number of endangered objects that have not lost their historical value in the Masovian voivodeship places them below half for different categories, arranging the set from the highest number/percentage value. However, it should be noted that almost every $12^{\text {th }}$ historic residential building is at risk. What makes it more problematic from a protection point of view is that many of those buildings are private, impeding security works.

\section{Characteristics}

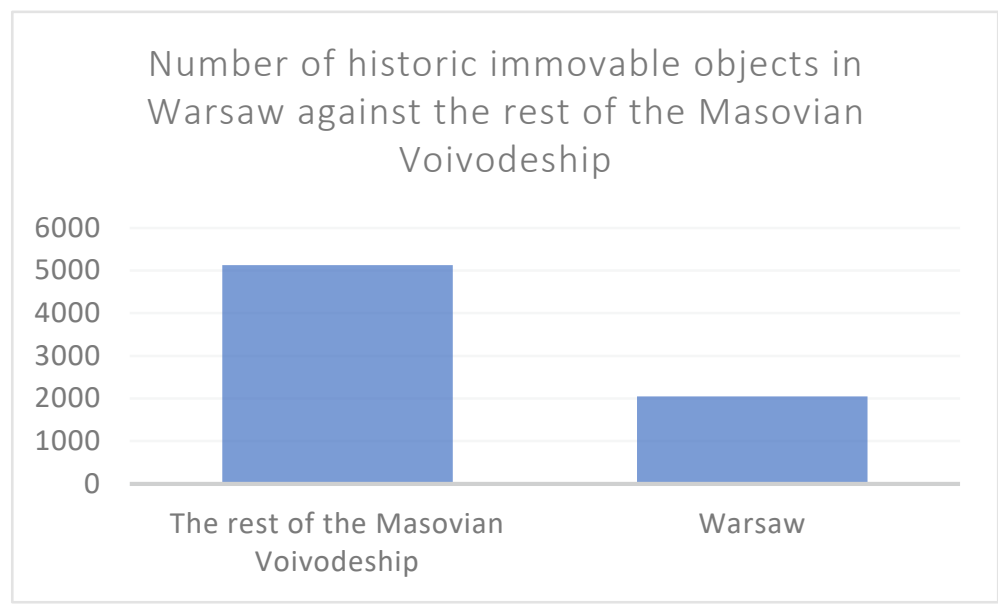

The research covers the area of Mazowieckie Voivodeship with the exclusion of Warsaw. The exclusion was applied because of the highly individual aspects of the capital city with strengthened investment forces and severe World War II destruction [3]. The number of listed buildings in Warsaw (2047) makes 29.05\% of Voivodeship's total number.

The researched items are listed in reports developed by the National Heritage Board of Poland [1] [2] and are under law protection. The initial division for the state of preservation in the mentioned reports included:

- endangered,

- loss of value,

- not existing,

- relocation,

not identified

- relocation to museums [4].

This set was limited to endangered buildings as the rest did not represent the original value for which it was taken under protection in the first place. That created the group of 154 buildings. Moreover, as the research focuses on architectural heritage, exclusion of categories of cemeteries, greenery and other elements that are not buildings was applied. The heritage buildings described as ruins were excluded as being classified as a ruin does not imply endangerment, as examples of permanent ruins show.

That created the group of 120 endangered listed heritage buildings. As the report does not include specific buildings' names, the National Heritage Board of Poland provided a detailed list containing the register number, address, function, and location. That enabled in-depth analysis of the set.

The original list based on data gathered in the years 2009-2015 was updated by verifying materials such as satellite imagery, street view images and press articles. In the list, buildings that could be included in the set under discussion after report creation were not included. 


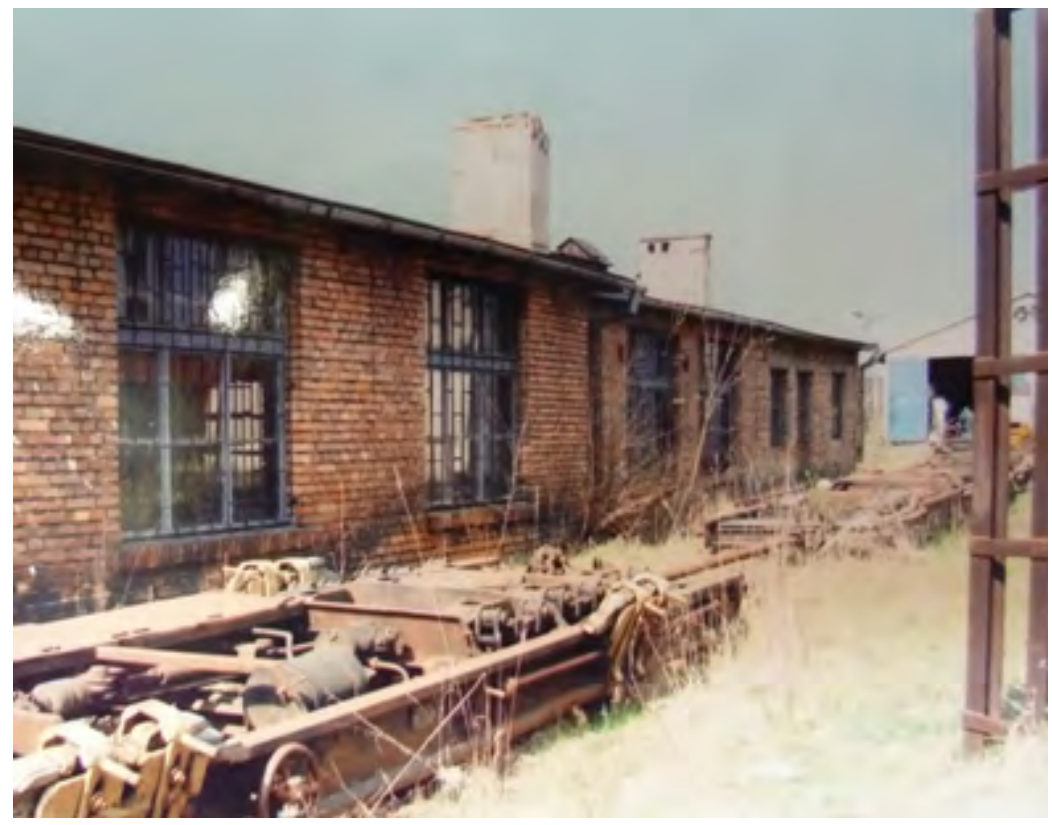

Fig. 1. One on the buildings in the Narrow-Gauge Railway in Mława, author: Wanda Gołębiewska

The County with the highest number of endangered buildings is Mławski County, with 21 buildings. This administrative unit list includes seven entries in the same group: Narrow-gauge Railway in Mława [5] [6]. When counting it as one position, this County would still take first place. The second place is Piaseczyński County (11 buildings). There are two Counties: Ciechanowski and Radomski, with 11 buildings in third place.

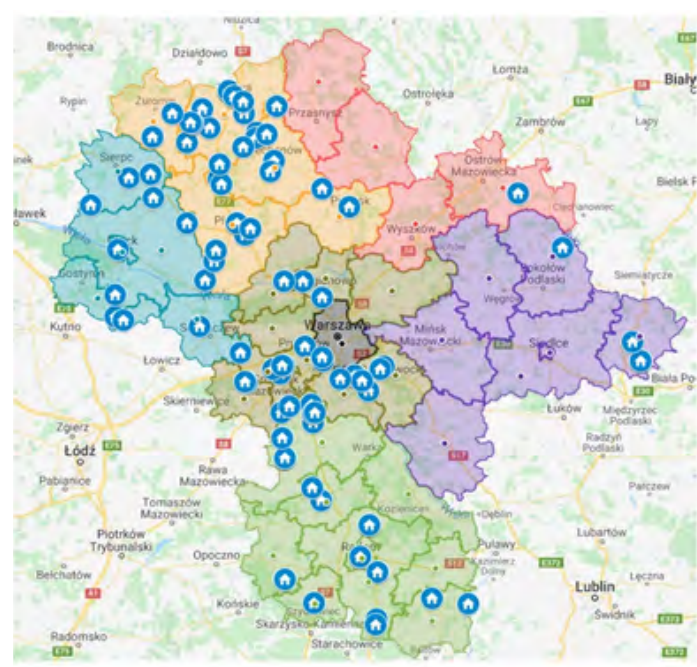

A Buildings

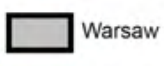

Delegation in Ciechanów with county towns

Delegation in Ostrolęka with county towns

Delegation in Plocku with county towns

Delegation in Siedlce with county towns

Rest of counties with county towns
Fig. 2. Map of Masovian Voivodeship presenting endangered heritage buildings with delegation areas and the exclusion of Warsaw

Considering the original functions of the endangered heritage buildings in the area in question, the group of residential buildings is the largest (40 buildings). In second place are farm buildings (19) and in the third housing (17).

From the chronological point of view, the group of buildings created in the XIX century is the biggest (64 buildings). In second place are buildings erected in the XX century (35) and the third XVI-XVIII century (19).

The verification of ownership and construction materials were not under verification.

Basing on the list of all the heritage buildings under law protection in Masovian Voivodeship (excluding Warsaw), a map was created. The map shows all entries from the list with delegation division. It can be observed that buildings' distribution in the terrain is not even. There are counties with no elements like Przasnyski County or Makowski County. There are also counties where many endangered buildings can be found, like Płoński 
County with five positions. The tendency that results from the created maps is that Counties in the western half of the Masovian Voivodeship have more heritage buildings at risk.

\section{Exemplary endangered heritage buildings}

The exemplary positions included in the set discussed in part 2 are:

1. Mansion in Gródkowo

2. Railway Station in Kopana

3. Mansion in Nużewo

4. Mansion in Góra

5. Mansion in Dziemabkowo

6. Mansion in Wiksin

7. Mansion in Kosuty

8. Mansion in Kąty

9. Palace in Borkowice

10. Hoffman type furnace in Iłża

Position 1 and 2 are thoroughly discussed underneath

\section{Mansion in Gródkowo, Płocki County}

It is a representation of the most numerous categories discussed previously. The mansion was created in the second part of the XIX century (one-story brick mansion) and the beginning of the XX century (two-story wing). In 1870-1886, the farm was developing intensively [7]. In 1897, a fire destroyed all the farm buildings. Kazimierz Dziewanowski bought the farm with all its assets from his mother. The buildings were not destroyed during World War I. In World War II, many family members were killed, and the rest were forced to move to Warsaw, leaving the mansion behind. After the war, the government took over the assets and created a state collective farm PGR Dzierżanowo. In the older part of the mansion, a school was located. Both buildings were adapted to the new partition that enabled creating employee housing. In 2013 the heirs, who live abroad, gained ownership of buildings. As for 2016, the terrain and fields were leased, and there was no information about planned securing works.

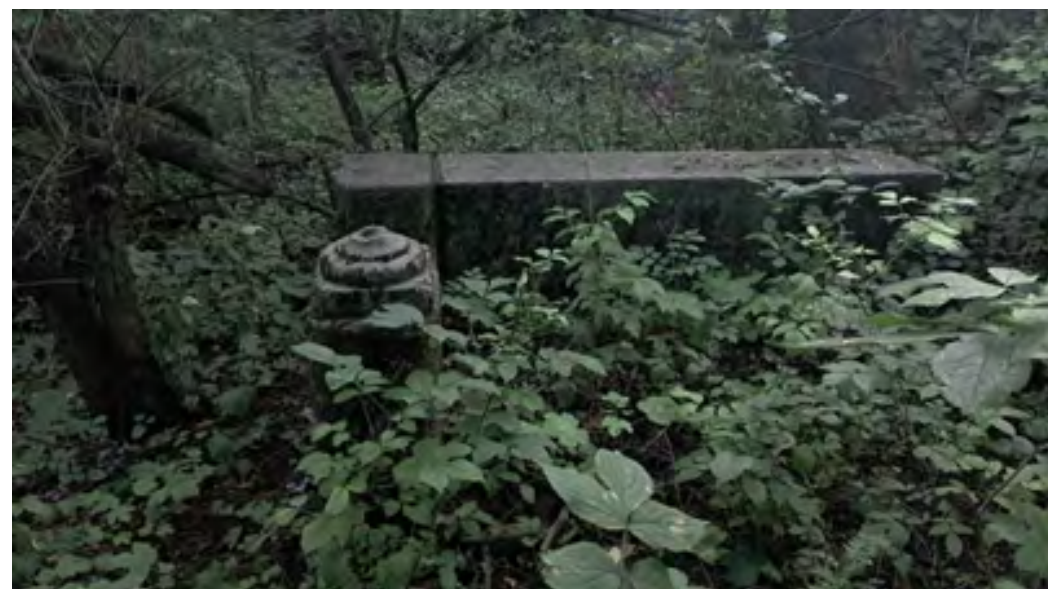

Fig. 3. Fragment of the porch in mansion in Gródkowo, own collection

The older part of the mansion is collapsed. The building's outline with a stone foundation, fragments of facade walls, and porch steps is visible in places. The two-story part has severe defects in the roof, ceiling, and stairs structure. 


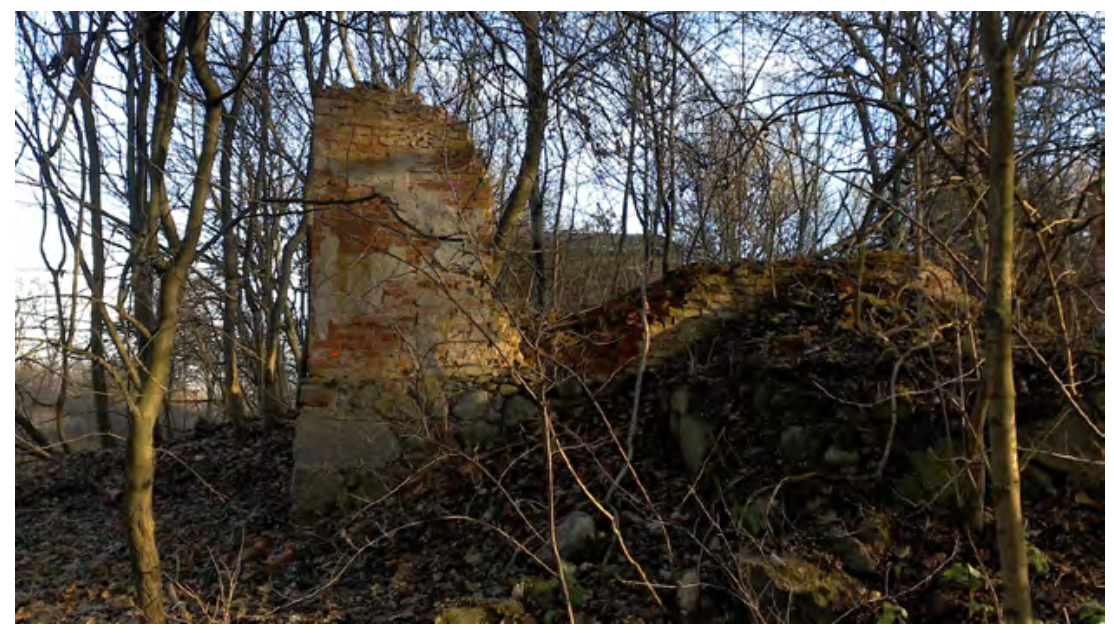

Fig. 4. Part of the elevation wall of the XIX century mansion in grówkowo, author's collection

\section{Railway Station in Kopana, Piaseczyński County}

Railway Station was a stop on not functioning the Grójecka Narrow-Gauge Railway route. The track construction started in from 1890 [8], and in 1914 it connected Warsaw with Grójec. Kopana station was located in the middle of this route.

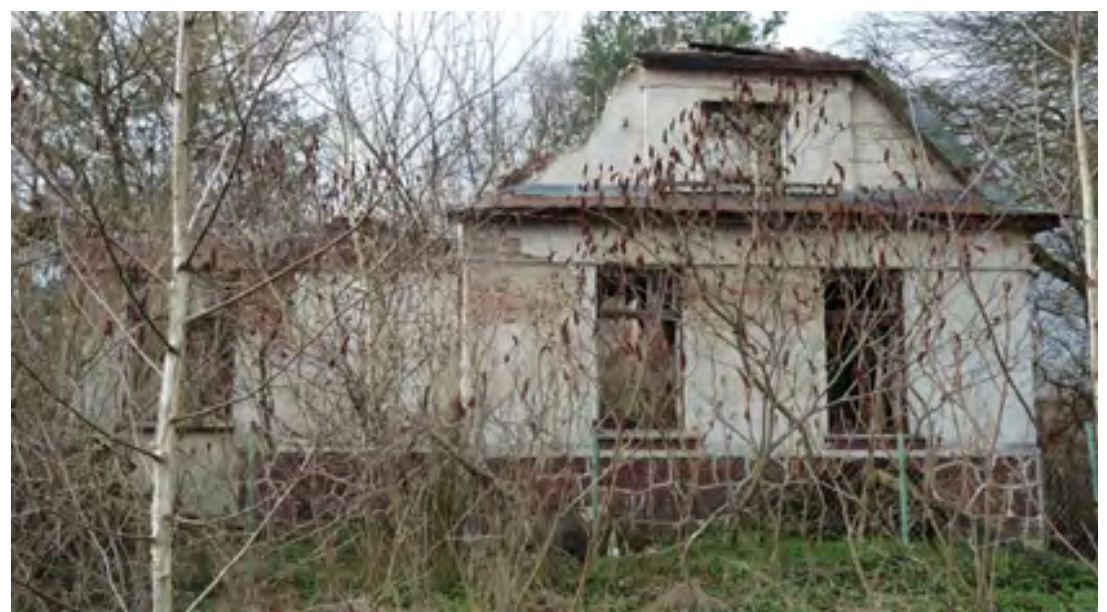

Fig. 5. Railway Station in Kopana, 2020, author's collection

The building was constructed in 1925. It is possible that the architect of it was Konstanty Jakimowicz. It is a three-storey ( 1 underground and 2 above ground) brick building, without accompanying objects. The roof is of half-hip type, referring to the polish country style.

In 2014 a fire destroyed an abandoned building [9]. That badly damaged the roof and ceiling structure, advancing the destruction process. There is no window joinery and no door joinery in most places.

\section{Summary}

The analysis of the endangered buildings under law protection performed for Masovian Voivodeship (excluding the Warsaw area) identified the groups that are most threatened with loss of heritage value. Such analysis can be performed for all voivodeships. 
According to the author, basing on such lists decision-makers could aim for additional work and financial resources to prevent further destruction. For buildings where restoration works are not possible, making a detailed inventory using, e.g. terrestrial laser scanners [10] could secure information about buildings' architectural form.

\section{Literature}

[1] Brudnicki J. i inni, Raport o Stanie Zachowania Zabytków Nieruchomych w Polsce. Zabytki Wpisane Do Rejestru Zabytków (Księgi Rejestru A i C), Warszawa 2017.

[2] Dymek A. i inni, Raport o Stanie Zachowania Zabytków Nieruchomych w Województwie Mazowieckim. Zabytki Wpisane Do Rejestru Zabytków (Księgi Rejestru A i C). Warszawa 2017.

[3] Czyżowicz-Malinowska M, Menes J, Piekut B., Raport o stratach wojennych Warszawy. Warszawa 2005.

[4] Kłoczko A., Szałygin J., Popławska-Bukało E., Lorek A., Sprawozdanie krajowe z weryfikacji rejestru zabytków nieruchomych, proeadzonej przez Oddziaty Terenowe NID: lata 2009-2010, Kurier Konserwatorski, 2012, nr 12.

[5] Maraśkiewicz D. Karta ewidencyjna zabytku nieruchomego wpisanego do rejestru zabytków. Lokomotywownia, w zespole dworca kolejki wąskotorowej, 2018.

[6] Taylor Z., Ciechański A., Recent organizational and ownership transformation in rail-transport companies in Poland-Part II, Przegląd Geograficzny, 2011, nr 83 z. 2, s. 205-231.

[7] Dziewanowski S., Opis i reorganizacja Majątku Grodkowo, Warszawa 1930.

[8] Helbrecht G., Baran J., Piaseczyńska Kolej Wąskotorowa jako element sieci komunikacji podmiejskiej miasta Warszawy, Logistyka, 2021, nr 6.

[9] http://kurierpoludniowy.pl/wiadomosci.php?art=13535

[10] Mitka B., Usability of terrestrial laser scanners for the process of documentation and modelling of historical objects, Archiwum Fotogrametrii, Kartografii i Teledetekcji, 2007, Vol. 17b. 